\title{
Seroprevalence and risk factors for Trypanosoma evansi, the causative agent of surra, in the dromedary camel (Camelus dromedarius) population in Southeastern Algeria
}

\begin{tabular}{|c|c|}
\hline $\begin{array}{l}\text { Authors: } \\
\text { Mohammed } \\
\text { Nora Mimoun } \\
\text { Younes Bentri } \\
\text { Tahar Kernif }^{3} \\
\text { Abdelaziz Bou } \\
\text { Curtis R. Youn } \\
\text { Rachid Kaidi } \\
\text { Bernard Faye }^{6} \\
\text { Youcef Halis }^{1}\end{array}$ & $\begin{array}{l}\text { Benaissa }{ }^{1} \text { (D) } \\
\text { khelkhal }^{1} \text { (D) } \\
\mathrm{ss}^{4} \text { (D) } \\
\end{array}$ \\
\hline \multicolumn{2}{|c|}{$\begin{array}{l}\text { Affiliations: } \\
{ }^{1} \text { Scientific and Technical } \\
\text { Research Centre for Arid } \\
\text { Areas (CRSTRA), Biophysical } \\
\text { Station, Nezla, Touggourt, } \\
\text { Algeria }\end{array}$} \\
\hline \multicolumn{2}{|c|}{$\begin{array}{l}{ }^{2} \text { National High School of } \\
\text { Veterinary Medicine, } \\
\text { Bab-Ezzouar, Algiers, Algeria }\end{array}$} \\
\hline \multicolumn{2}{|c|}{$\begin{array}{l}{ }^{3} \text { Laboratoire d'Eco- } \\
\text { épidémiologie Parasitaire et } \\
\text { Génétique des Populations, } \\
\text { Institut Pasteur d'Algérie, } \\
\text { Algiers, Algeria }\end{array}$} \\
\hline \multicolumn{2}{|c|}{$\begin{array}{l}{ }^{4} \text { Animal Science Department, } \\
\text { lowa State University, Ames, } \\
\text { United States of America }\end{array}$} \\
\hline \multicolumn{2}{|c|}{$\begin{array}{l}{ }^{5} \text { Institute of Veterinary } \\
\text { Sciences, LBRA, University of } \\
\text { Blida, Soumaa, Blida, Algeria }\end{array}$} \\
\hline \multicolumn{2}{|c|}{$\begin{array}{l}{ }^{6} \text { UMR SELMET, CIRAD-ES, } \\
\text { Montpellier, France }\end{array}$} \\
\hline \multicolumn{2}{|c|}{$\begin{array}{l}\text { Corresponding author: } \\
\text { Mohammed Benaissa, } \\
\text { ben.medhocine@gmail.com }\end{array}$} \\
\hline $\begin{array}{l}\text { Dates: } \\
\text { Received: } 21 \mathrm{~J} \\
\text { Accepted: } 14 \\
\text { Published: } 21\end{array}$ & $\begin{array}{l}\text { une } 2020 \\
\text { Dct. } 2020 \\
\text { Dec. } 2020\end{array}$ \\
\hline \multicolumn{2}{|l|}{ Read online: } \\
\hline 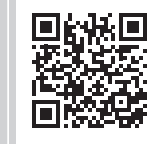 & $\begin{array}{l}\text { Scan this QR } \\
\text { code with your } \\
\text { smart phone or } \\
\text { mobile device } \\
\text { to read online. }\end{array}$ \\
\hline
\end{tabular}

\begin{abstract}
Surra, caused by Trypanosoma evansi, is a re-emerging animal trypanosomosis, which is of special concern for camel-rearing regions of Africa and Asia. Surra decreases milk yield, lessens animal body condition score and reduces market value of exported animals resulting in substantial economic losses. A cross-sectional seroprevalence study of dromedary camels was conducted in Algeria, and major risk factors associated with infection were identified by collecting data on animal characteristics and herd management practices. The seroprevalence of T. evansi infection was determined in sera of 865 camels from 82 herds located in eastern Algeria using an antibody test (card agglutination test for Trypanosomiasis - CATT/T. evansi). Individual and herd seroprevalence were $49.5 \%$ and $73.2 \%$, respectively, indicating substantial exposure of camels to T. evansi in the four districts studied. Five significant risk factors for T. evansi hemoparasite infection were identified: geographical area, herd size, husbandry system, accessibility to natural water sources and type of watering. There was no association between breed, sex or age with T. evansi infection. Results of this study provide baseline information that will be useful for launching control programmes in the region and potentially elsewhere.
\end{abstract}

Keywords: seroprevalence; Trypanosoma evansi; Camelus dromedarius; camels; Algeria.

\section{Introduction}

Trypanosomiasis is a significant animal and human health problem worldwide. Human African trypanosomiasis (sleeping sickness) is caused by infestation with the flagellate protozoan Trypanosoma brucei, whereas animal trypanosomiasis is caused by different species and subspecies of Trypanosoma (T. congolense, T. vivax, T. brucei brucei and T. brucei evansi). Amongst all of the trypanosomiases, 'surra' (caused by Trypanosoma brucei evansi) has the widest host range and the broadest geographical distribution. It is transmitted mechanically by the bite of infected tabanid flies; Family: Tabanidae (Desquesnes et al. 2009); Genus: Tabanus, Muscidae stomoxys, Haematopota, Lyperosia spp. and Chrysops spp. (Luckins 1998), or infected vampire bats (Stoco et al. 2017). Transmission occasionally occurs iatrogenically through herd identification and vaccination procedures (Gutierrez et al. 2005), and oral transmission was confirmed recently in a mouse model (Mandal et al. 2017).

Trypanosomosis serves as an important constraint to camel production because it substantially reduces animal productivity, thus inducing economic losses. It is a major endemic disease problem throughout Central and South America, Africa and Asia (Gutierrez et al. 2000). Infection with T. brucei evansi (hereafter, T. evansi) reduces market value of exported animals, decreases milk yield and lessens animal body condition score, resulting in more than \$223 million loss to the camel industry (Salah, Robertson \& Mohamed 2015). In addition to causing the aforementioned losses, T. evansi is the most important cause of infectious abortions in camels in the Middle East and Africa (Boushaki et al. 2019; More et al. 2017). Camels with clinical disease can present progressive emaciation, severe anaemia, reproductive problems (because of infertility, abortions and stillbirths), and eventually death (Desquesnes et al. 2013).

In Algeria, T. evansi was first detected in 1903 in infected camels (Sergent \& Sergent 1905). Since that time, few studies have been performed on livestock, and most were conducted in a

How to cite this article: Benaissa, M.H., Mimoune, N., Bentria, Y., Kernif, T., Boukhelkhal, A., Youngs, C.R. et al., 2020, 'Seroprevalence and risk factors for Trypanosoma evansi, the causative agent of surra, in the dromedary camel (Camelus dromedarius) population in Southeastern Algeria', Onderstepoort Journal of Veterinary Research 87(1), a1891. https://doi.org/10.4102/ojvr.v87i1.1891

Copyright: ๑ 2020. The Authors. Licensee: AOSIS. This work is licensed under the Creative Commons Attribution License. 
limited geographical area with a limited number of samples (Benfodil et al. 2020; Bennoune et al. 2013; Boushaki et al. 2019); those studies concluded only that the hemoparasite can be detected in blood samples. Limited data are available currently concerning the epidemiology and distribution of the T. evansi parasite in Algeria. To gauge levels of endemic stability, it is important to assess the seroprevalence of T. evansi and to characterise local variations in risk factors.

To help fill the scientific knowledge gap regarding this important disease, the present study was conducted with the objectives of determining the seroprevalence of T. evansi and investigating potential risk factors for infection with T. evansi in the one-humped camel (Camelus dromedarius) population in eastern Algeria.

\section{Materials and methods}

\section{Study area}

This study was carried out in four districts (Biskra, El-Oued, Ouargla and Ghardaia) in eastern Algeria. These provinces are located at 00204-00735 E and 28 $8^{\circ} 32-34^{\circ} 56 \mathrm{~N}$ (Figure 1). This region is considered as one of the most significant camel-rearing areas in Algeria, and it is a region where camel milk is increasingly commercialised and consumed. The climate of this region is arid and is characterised by long, hot summers and short, mild winters.

\section{Data collection}

Data were collected using a paper-based questionnaire given to herd owners by trained investigators. The study questionnaire focused on 23 potential explanatory variables grouped by: (1) pastoralists' socio-demographic characteristics (gender, age, occupation and formal education); (2) individual camel data (age class $[<1$ year, 1-3 years, 4-9 years, 10-15 years and $>15$ years; ages were assigned based on dental wear and owner information], sex [male, female], breed [Sahraoui, Tergui]); and (3) herd data (location [district], herd size [small: < 10 head, medium: 11-30 head, large: $>30$ head], the introduction of new camels bought at a livestock market [yes or no], presence of other domestic animal species [sheep, goats, cattle; yes or no], epidemiological characteristics [occurrence of abortions in the herd], exchange of bulls for mating [yes or no] and animal management system).

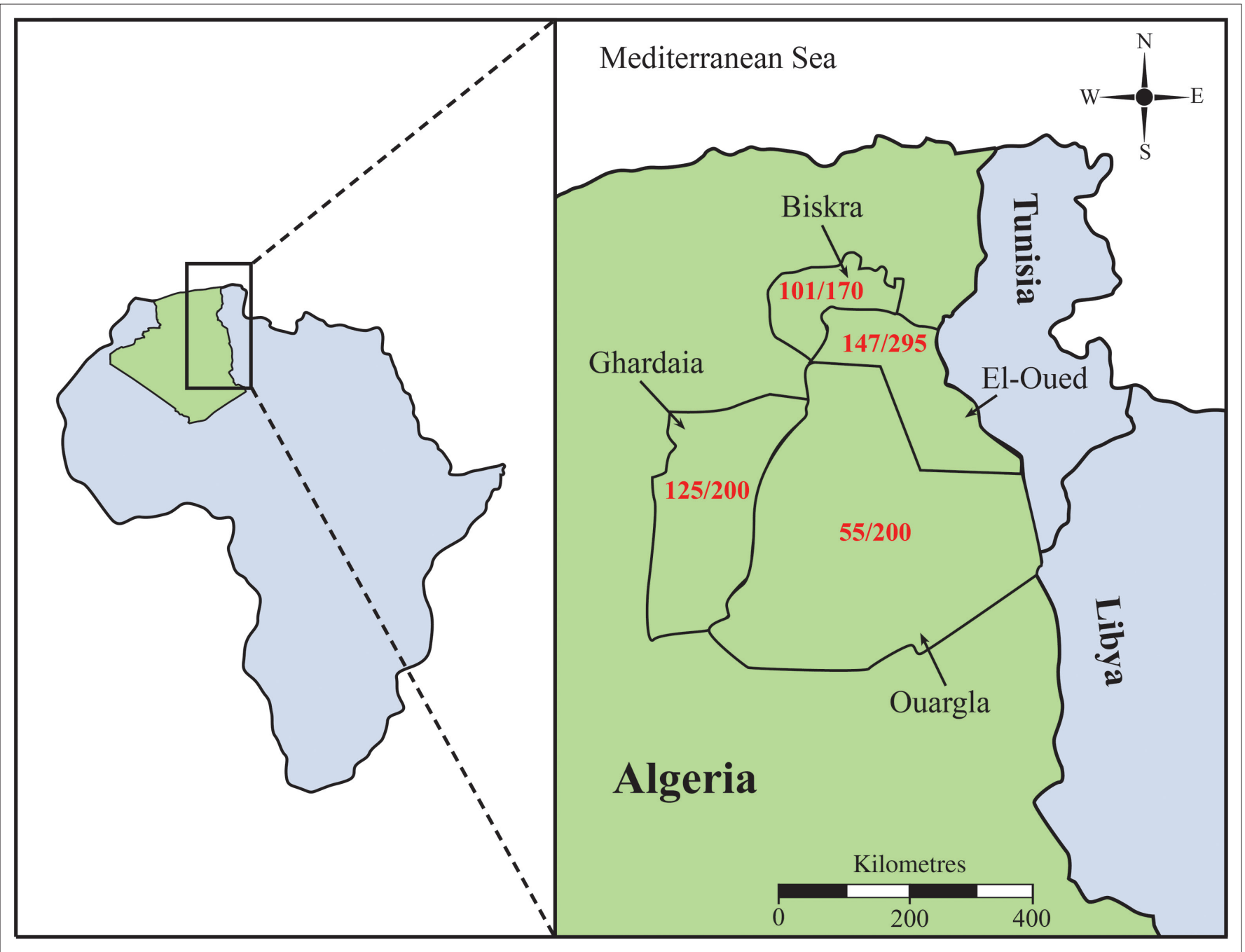

FIGURE 1: Distribution of Trypanosoma evansi seropositivity in dromedary camels in four districts in southeastern Algeria. Numbers in red indicate the number of camels seropositive for Trypanosoma evansi as a proportion of animals tested in the Biskra, El-Oued, Ghardaia and Ouargla districts. 


\section{Sample size determination}

The minimal sample size required for this study was determined using the random sampling method (Thrusfield 2018), considering an expected prevalence of $35 \%$ (based on unpublished survey data collected in 2008 in seven districts in Algeria) with 5\% precision at the 95\% confidence level. The formula used for calculation of sample size was:

$$
N=(1.96)^{2} \times \frac{P(1-P)}{d^{2}}
$$

where $N=$ number of sample size, $P=$ expected prevalence and $d^{2}=$ absolute precision.

Although the minimum sample size calculated for this study was 350 animals, we increased the number of samples collected to improve the degree of accuracy and to account for some potential sample losses.

\section{Sample collection and processing}

A total of 865 blood samples were collected in a randomised manner. A total of $10 \mathrm{~mL}$ of blood was collected by jugular venipuncture. Blood samples remained at room temperature for $3-5 \mathrm{~h}$ to allow clotting, followed by centrifugation for $15 \mathrm{~min}$ at 3000 revolution per minute (rpm). The serum fraction was extracted with a micropipette, and serum samples were frozen at $-20{ }^{\circ} \mathrm{C}$ until analysis.

Sera were tested for the presence of anti-T. evansi antibodies using a commercially available direct card agglutination test (card agglutination test [CATT] for trypanosomiasis, T. evansi kit, Institute of Tropical Medicine, Antwerp, Belgium) according to the manufacturer's instructions. Approximately, $45 \mu \mathrm{L}$ of test reagent was transferred onto the test card and was mixed with an equal volume of the test sera diluted 1:4 with CATT buffer. The test card was rotated for $5 \mathrm{~min}$ at $70 \mathrm{rpm}$, after which time the reaction was checked carefully for agglutination. Positive reaction (evidence of agglutination) was determined by the quantitative presence of blue-colored granules (Bajyana-Songa \& Hamers 1988). Individuals with a positive CATT-P titer _1:4 result $(+=$ weak,$++=$ moderate, $+++=$ strong) were considered serologically positive.

\section{Statistical analysis}

Pearson's Chi-square test or Fisher's exact probability test were applied to test for significant associations between potential risk factors and the outcome variable (status of Trypanosoma seropositivity in camels) in a univariate analysis. Multivariate logistic regression models were carried out using all variables showing a tendency towards statistical significance ( $p$ value $£ 0.25$ ). The logistic regression model was developed with a step-wise forward approach using a likelihood ratio test at each step with a $p$ value of 0.10 as the significance level for removal or retention of the variable. In the final model, any variable with a $p$ value $<0.05$ was considered statistically significant. Model fit analysis was assessed with the Hosmer and Lemeshow goodness-of-fit test. All statistical analyses were performed using the
Statistical Package for Social Sciences (SPSS) version 17.0 (SPSS Inc., Chicago, IL, United States [US]).

\section{Ethical consideration}

Animal sampling was implemented with the approval of the national veterinary authorities and was exclusively done by veterinarians; the animals were blood-sampled without suffering and were subsequently released. Farmers in each zone gave verbal consent to participate in our study and gave permission for the blood sample collection from camels on their property. We followed the European guidelines (European directives EU 86/609-STE123 and 2010/63/EU) for animal handling.

\section{Results Individual level}

Antibodies against T. evansi were detected in 428 of the 865 individual camels tested, giving an individual seroprevalence rate of $49.5 \%$ (95\% confidence interval [CI]: $46.1 \%-52.9 \%)$. At the herd level, 60 of the 82 herds tested had at least one seropositive animal, giving a herd seroprevalence rate of $73.2 \%$ (95\% CI: $62.2 \%-82.4 \%)$.

Results of the univariate analysis (Chi-square) revealed that individual animal seroprevalence for T. evansi was affected by geographical area, herd size, husbandry system, accessibility to natural water sources and type of watering (Table 1). Contrarily, no differences $(p>0.05)$ were demonstrated in trypanosomosis seroprevalence because of genetic sex, breed or animal age.

There was a very strong association between T. evansi seroprevalence and geographical area $\left(\chi^{2}=4.80, p<\right.$ $0.0001)$. The highest infection rate $(62.5 \%, 125 / 200)$ was found in Ghardaia (northern part of the Sahara region), whereas the district of Ouargla had the lowest infection rate $(27.5 \%, 55 / 200)$. The analysis showed that camels raised in large herds had a higher $(p<0.007)$ incidence of T. evansi infection compared with those raised in small herds.

Regarding the multivariate logistic regression analyses (Table 2), three variables remained in the final model: (1) herd size, (2) husbandry system and (3) water source. The odds of $T$. evansi infection were 2.2 times higher amongst large camel farms $(p=0.007$, odds ratio $[\mathrm{OR}]=2.159 ; 95 \%$ $\mathrm{CI}=1262-3693)$ compared with small herds. Herds with more than 50 camels were 2.1 times more likely to have a seropositive animal than herds with fewer than 10 head. The presence of natural sources of water in nearby grazing areas was associated with an increased risk of T. evansi infection $(\mathrm{OR}=9.415 ; 95 \% \mathrm{CI}=1.256-70,583)$. Animals in a semi-intensive management system were more likely to be infected $(\mathrm{OR}=2.95 ; 95 \% \mathrm{CI}: 1.878-4.645)$ than extensively managed animals. 
TABLE 1: Factors associated with animal-level seroprevalence of antibodies against Trypanosoma evansi for dromedary camel populations of southeastern Algeria.

\begin{tabular}{|c|c|c|c|c|c|c|c|}
\hline \multirow[t]{3}{*}{ Factor } & \multirow[t]{3}{*}{ Category } & \multirow[t]{3}{*}{ Number of animals } & \multicolumn{4}{|c|}{ Serum $T$. evansi antibodies } & \multirow[t]{3}{*}{$p^{*}$} \\
\hline & & & \multicolumn{2}{|c|}{ Positive } & \multicolumn{2}{|c|}{ Negative } & \\
\hline & & & $n$ & $\%$ & $n$ & $\%$ & \\
\hline \multirow{4}{*}{$\begin{array}{l}\text { Geographic location } \\
\text { (district) }\end{array}$} & Ouargla & 200 & 55 & 27.5 & 145 & 72.5 & 0.000 \\
\hline & Biskra & 170 & 101 & 59.4 & 69 & 40.6 & \\
\hline & El-Oued & 295 & 147 & 49.8 & 148 & 50.2 & \\
\hline & Ghardaia & 200 & 125 & 62.5 & 75 & 37.5 & \\
\hline Sex & Female & 829 & 407 & 49.1 & 422 & 50.9 & \\
\hline \multirow[t]{5}{*}{ Age class } & 1 (< 1 year) & 7 & 4 & 57.1 & 3 & 42.9 & 0.158 \\
\hline & 2 (1-3 years) & 127 & 55 & 43.3 & 72 & 56.7 & \\
\hline & 3 (4-9 years) & 304 & 140 & 46.1 & 164 & 53.9 & \\
\hline & 4 (10-15 years) & 131 & 72 & 55.0 & 59 & 45.0 & \\
\hline & 5 (> 15 years) & 296 & 157 & 53.0 & 139 & 47.0 & \\
\hline Breed & Sahraoui & 722 & 349 & 48.3 & 373 & 51.7 & 0.131 \\
\hline \multirow[t]{3}{*}{ Herd size } & Large (> 50 head) & 625 & 325 & 52.0 & 300 & 48.0 & 0.010 \\
\hline & Medium & 159 & 75 & 47.2 & 84 & 52.8 & \\
\hline & Small (<20 head) & 81 & 28 & 34.6 & 53 & 65.4 & \\
\hline \multirow[t]{3}{*}{ Husbandry system } & Extensive & 564 & 243 & 43.1 & 321 & 56.9 & 0.000 \\
\hline & Semi-intensive & 150 & 100 & 66.7 & 50 & 33.3 & \\
\hline & Intensive & 151 & 85 & 56.3 & 66 & 43.7 & \\
\hline \multirow{2}{*}{$\begin{array}{l}\text { Access to natural } \\
\text { water sources }\end{array}$} & Yes & 411 & 265 & 64.5 & 146 & 35.5 & 0.000 \\
\hline & No & 454 & 163 & 38.9 & 291 & 64.1 & \\
\hline \multirow[t]{2}{*}{ Watering system } & Artificial wells & 562 & 257 & 45.7 & 305 & 54.3 & 0.003 \\
\hline & Lakes and streams & 303 & 171 & 56.4 & 132 & 43.6 & \\
\hline
\end{tabular}

*, Univariate analyses $\left(\gamma^{2}\right.$ test for significance).

TABLE 2: Risk factors for individual-level infection with Trypanosoma evansi amongst dromedary camel populations in southeastern Algeria.

\begin{tabular}{lccccc}
\hline Factor & B & Std err & OR & 95\% Cl(OR) & $p$ value* \\
\hline Constant & -1.028 & 0.273 & - & - & 0.000 \\
Herd size & & & & & 0.007 \\
Large & 0.769 & 0.274 & 2.159 & $1.262-3.693$ & 0.005 \\
Medium & 0.263 & 0.305 & 1.300 & $0.715-2.365$ & 0.390 \\
Husbandry system & & & & & 0.000 \\
Intensive & 0.766 & 0.227 & 2.151 & $1.380-3.355$ & 0.001 \\
Semi-intensive & 1.083 & 0.231 & 2.954 & $1.878-4.645$ & 0.000 \\
Water courses & 2.242 & 1.028 & 9.415 & $1.256-70.583$ & 0.000 \\
\hline
\end{tabular}

Note: Model-2 log-likelihood 1090.211.

$\chi^{2}$ goodness of fit $=12.449 ; p$ value $=0.132$.

$\mathrm{B}$, logistic regression coefficient; Std err, standard error; OR, odds ratio; $\mathrm{Cl}$, confidence interval.

$*$, Model $\chi^{2}=108.8902$ with $10 \mathrm{df}$

\section{Herd level}

The univariate herd level analysis revealed five factors associated with $T$. evansi seropositivity (Table 3): geographical location $(p=0.004)$, husbandry system $(p=0.038)$, history of abortion $(p=0.005)$, herd size $(p=0.010)$, and nearby natural water sources $(p<0.05$; Table 3$)$. Trypanosoma evansi seroprevalence was higher $(p<0.001)$ in Ghardaia, Biskra and El-Oued than in Ouargla. In contrast, no association was found between T. evansi seropositivity of the herd and contact with other camel herds, husbandry system (nomadic) or introduction of purchased camels (Table 3).

The multivariate logistic regression model showed that the main risk factor associated with T. evansi infection in camel herds was geographical location (Table 4). The likelihood of detecting T. evansi antibodies was 11 times higher in the district of Ghardaia (OR = 11.25; 95\% CI [2.00-63.19]),
7.5 times higher in El-Oued (OR = 7.50; 95\% CI [2.02-27.86]) and 6 times higher in Biskra (OR $=6.00 ; 95 \% \mathrm{CI}$ [1.27-28.25]) than in the district of Ouargla (Table 4).

\section{Discussion}

To our knowledge, few studies have been performed in Algeria aimed at assessing risk factors associated with T. evansi infection of dromedary camels. Our results, which document high seroprevalence rates at the individual and herd levels, could ultimately guide the design and implementation of enhanced surveillance programmes, control measures and prevention strategies for T. evansi not only in eastern Algeria but throughout major camel producing regions of the world.

In Algeria, T. evansi infection in camels was confirmed for the first time more than a century ago when parasitological examinations discovered that $10 \%$ of 282 camels were infected (Sergent \& Sergent 1905). Outbreaks of trypanosomosis in dromedary herds associated with mortalities and abortions have been documented (Boushaki et al. 2019). The T. evansi seropositivity rate in our study $(49.5 \%)$ was higher than previous serological studies conducted in Algeria by Benfodil et al. (2020) and Boushaki et al. (2019), who reported seroprevalence up to $32.4 \%$, and $9.9 \%$, respectively. The higher seroprevalence in the present study could be because of the differences in the topography of the study areas, age of tested animals, proportion of males versus females, sample size, environmental conditions during the sampling period, or differences in diagnostic methods. 
TABLE 3: Factors associated with animal-level seroprevalence of antibodies against Trypanosoma evansi for dromedary camel populations of southeastern Algeria.

\begin{tabular}{|c|c|c|c|c|c|c|c|}
\hline \multirow[t]{3}{*}{ Factor } & \multirow[t]{3}{*}{ Category } & \multirow[t]{3}{*}{ Number of herds } & \multicolumn{4}{|c|}{ Serum $T$. evansi antibodies } & \multirow[t]{3}{*}{$p^{*}$} \\
\hline & & & \multicolumn{2}{|c|}{ Positive } & \multicolumn{2}{|c|}{ Negative } & \\
\hline & & & $n$ & $\%$ & $n$ & $\%$ & \\
\hline \multirow[t]{4}{*}{ Geographic location (district) } & Ouargla & 21 & 9 & 42.9 & 12 & 57.1 & $0.004 *$ \\
\hline & Biskra & 15 & 12 & 80.0 & 3 & 20.0 & \\
\hline & El-Oued & 28 & 23 & 82.1 & 5 & 17.9 & \\
\hline & Ghardaia & 18 & 16 & 88.9 & 2 & 11.1 & \\
\hline \multirow[t]{2}{*}{ Contact with other camel herds } & Yes & 75 & 55 & 73.3 & 20 & 26.7 & 0.902 \\
\hline & No & 7 & 5 & 71.4 & 2 & 28.6 & \\
\hline \multirow[t]{3}{*}{ Husbandry system } & Extensive & 53 & 34 & 64.2 & 19 & 35.8 & $0.038 *$ \\
\hline & Semi-intensive & 16 & 15 & 93.7 & 1 & 6.3 & \\
\hline & Intensive & 13 & 11 & 84.6 & 2 & 15.4 & \\
\hline \multirow[t]{2}{*}{ Divagation } & Yes & 36 & 28 & 77.8 & 8 & 22.2 & 0.405 \\
\hline & No & 46 & 32 & 69.6 & 14 & 30.4 & \\
\hline History of abortion & Yes & 27 & 25 & 92.6 & 2 & 7.4 & $0.005 *$ \\
\hline \multirow[t]{2}{*}{ Introduction of purchased animals } & Yes & 44 & 33 & 75.0 & 11 & 25.0 & 0.687 \\
\hline & No & 38 & 27 & 71.1 & 11 & 28.9 & \\
\hline \multirow[t]{2}{*}{ Watering type } & Artificial wells & 43 & 26 & 60.5 & 17 & 39.5 & $0.006 *$ \\
\hline & Lakes and streams & 39 & 34 & 87.2 & 5 & 12.8 & \\
\hline \multirow[t]{2}{*}{ Contact with sheep and goats } & Yes & 32 & 23 & 71.9 & 9 & 28.1 & 0.832 \\
\hline & No & 50 & 37 & 74.0 & 13 & 26.0 & \\
\hline \multirow{2}{*}{$\begin{array}{l}\text { Accessibility to natural water } \\
\text { sources }\end{array}$} & Yes & 50 & 41 & 82.0 & 9 & 18.0 & $0.024 *$ \\
\hline & No & 32 & 19 & 59.4 & 13 & 40.6 & \\
\hline \multirow[t]{3}{*}{ Educational level of farmer } & Primary education & 32 & 21 & 56.6 & 11 & 34.4 & 0.467 \\
\hline & Illiterate & 41 & 32 & 78.0 & 9 & 22.0 & \\
\hline & University & 9 & 7 & 77.8 & 2 & 22.2 & \\
\hline
\end{tabular}

Note: An increase in herd size was associated with an increase in seropositivity $(p<0.001)$.

$*$, Univariate analyses $\left(\chi^{2}\right.$ test for significance).

TABLE 4: Risk factors for herd-level infection with Trypanosoma evansi amongst dromedary camel populations in southeastern Algeria.

\begin{tabular}{lccccc}
\hline Category & $\mathbf{B}$ & Std err & OR & $\mathbf{9 5 \% ~ C l ~ ( O R ) ~}$ & $\boldsymbol{p}^{*}$ \\
\hline Constant & -0.405 & 0.456 & - & - & 0.374 \\
Geographic & - & - & - & - & 0.005 \\
location (district) & & & & & \\
Ouargla & Reference & - & - & - & - \\
Biskra & 1.792 & 0.791 & 6.000 & $1.274-28.254$ & 0.023 \\
El-Oued & 2.015 & 0.670 & 7.500 & $2.019-27.862$ & 0.003 \\
Ghardaia & 2.420 & 0.147 & 11.250 & $2.004-63.198$ & 0.006 \\
\hline
\end{tabular}

Note: Model-2 log-likelihood 81.281.

$\chi^{2}$ goodness of fit $=0.000 ; p$ value $=1.000$

$\mathrm{B}$, logistic regression coefficient; Std err, standard error; OR, odds ratio; $\mathrm{Cl}$, confidence interval.

$*$, Model $\chi^{2}=14.093$ with $3 \mathrm{df}$.

However, the T. evansi seroprevalence rate in our study $(49.5 \%)$ is highly consistent with the findings from studies conducted in other developing countries that revealed T. evansi seroprevalence rates of $46 \%$ in Burkina Faso (Dia 2006), 45.9\% in Kenya (Njiru et al. 2004), 43.8\% in Saudi Arabia (El-Wathig \& Faye 2013), 43.5\% in Egypt (Abdel-Rady 2008) and $47.7 \%$ in Pakistan (Tehseen et al. 2015). One study in Somalia reported a higher T. evansi seroprevalence rate $(56.4 \%)$ than that found in our study (Baumann \& Zessin 1992). Thus, we interpret our results as being in line with results from several studies conducted in other camel-producing regions of the world.

Researchers in various African and Middle Eastern countries found lower T. evansi seroprevalence rates than ours. One study in Jordan found a 33\% infection rate
(Al-Rawashdeh et al. 1999) whilst in eastern Chad a 30.5\% seroprevalence rate, detected using the CATT test, was reported (Delafosse \& Doutoum 2004). Even lower rates of T. evansi seroprevalence were reported in the African nations of Ethiopia (between 18.2\% and 24.9\%; Aregawi et al. 2015; Bogale, Kelemework \& Chanie 2012; Fikru et al. 2015; Hagos et al. 2009), Mauritania (24\%, Dia et al. 1997), Niger (12\%, Pacholek et al. 2000) and Tanzania (8.3\%, Njiru et al. 2002). Others reports of low T. evansi seroprevalence came from UAE (10.67\%, Chaudhary \& Iqbal 2000), Iran (10\%, Zarif-Fard \& Hashemi-Fesharki 2000) and Pakistan (4\%, Hasan et al. 2006). The heterogeneity between seroprevalence rates in different parts of the world is likely because of the differences in density of camel rearing, animal husbandry systems, climatic conditions, density of mechanical vectors, local herd management practices, study sample sizes, as well as cut-off values and sensitivity differences in the serological tests employed. Moreover, in our study location, poor-quality veterinary service, divagation and migration of camels to humid area and northland areas in search of feed (Benaissa et al. 2012) might have additionally contributed to the high seroprevalence. Under such production conditions, it will be important to educate camel farmers how to mitigate risks of T. evansi infection.

At the herd level, our study demonstrated wide distribution of camel trypanosomosis. Indeed, $73.2 \%$ of herds (60 of 82 tested herds) had at least one seropositive animal. Our overall herd seroprevalence is comparable to the 
$80 \%$ herd T. evansi seroprevalence reported recently in Somalia (Mohamed et al. 2020).

Our study documents a high prevalence of this diseasecausing parasite and corroborates field observations of substantial waves of mortality and abortion reported by camel farmers and veterinarians in the region. The high herdlevel seroprevalence supports field reports of marked financial impacts of this disease and indicates the need to develop field-practical control and prevention programmes.

Although few studies have addressed herd-level seroprevalence, our seropositivity result was much higher than the $42.3 \%$ reported earlier in Algeria (Boushaki 2007). Given the span of time between studies, our study highlights the continued circulation of the parasite within herds in the region as well as its endemicity. In uncontrolled situations, herd-level seroprevalence could reach as high as $94.9 \%$ (Delafosse \& Doutoum 2004). In fact, two important risk factors identified at the individual level in the former study (contact between herds and introduction of new camels into the herd) support that infection can easily spread from one herd to the other.

No effect of camel age on T. evansi seropositivity was observed in our study. Our finding agrees with some surveys (Boushaki et al. 2019; Pathak \& Khanna 1995; Shah et al. 2004), but differs from those of other research groups who reported increased seroprevalence with increasing age (Atarhouch et al. 2003; Bogale et al. 2012; Dia et al. 1997; Eshetu, Desta \& Amare 2013; Gutierrez et al. 2000; Mirshekar, Yakhchali \& Shariati-Sharifi 2017; Olani et al. 2016; Tehseen et al. 2015). In contrast to the above findings, one study in Ethiopia revealed higher infection rates in younger camels than in older adult camels (Lemecha, Lidetu \& Hussein 2008). These conflicting results suggest that future investigations need to be designed to specifically test the hypothesis of age effects on T. evansi seropositivity.

The risk of contracting trypanosomosis in semi-intensive and intensive systems was approximately three and two times higher, respectively, than in extensive management systems in our study. This result agrees with previous reports that husbandry systems and practices have a great impact on circulation of T. evansi (Dia et al. 1997). Serological surveys conducted in Sudan detected a higher prevalence of T. evansi in nomadic camels than in camels managed in an agropastoral system (Elamin, El Bashir \& Saeed 1998). Camel husbandry systems are frequently characterised by a remarkably high level of animal mobility and exchange between farms and areas, and even between countries (e.g., Algeria, Tunisia, Libya, Mali, and Niger). These highly common movements (controlled or uncontrolled) of camels could explain the wide distribution of T. evansi infection.

An association between camel seropositivity for T. evansi and herd history of abortion was observed in our study. This finding is in good agreement with a recent epidemiological study where abortion was associated with
T. evansi seropositivity (Boushaki et al. 2019). This result was not unexpected, as abortions induced by T. evansi have been reported in other species. Unfortunately, data concerning the incidence of abortions and other productivity measures are frequently lacking in camel-dependent livestock production settings.

Herd T. evansi seropositivity rates varied greatly between geographical areas. The highest risk of camel trypanosomosis was observed in Ghardaia (a region with relatively cold climate). Ghardaia and Biskra, situated in the northern Algerian Sahara, have an abundance of naturally occurring water sources that are associated with higher rates of T. evansi seropositivity. Although our study area belongs to the arid climate stage, it remains rich in natural water resources, with several rivers as well as temporary lakes and wadis appearing during the rainy season. We interpret our results to mean that these natural water sources likely enhance the spread of trypanosomosis through the development and proliferation of tabanids, which are indiscriminate in the transmission of $T$. evansi. Because these vectors seem subservient to standing water (ponds and lakes), regions with wetlands and saline lakes can be identified as higher risk areas as reported recently in a study in seven others provinces of southern Algeria (Boushaki et al. 2019).

Worldwide, several authors have reported considerable differences in the seroprevalence of $T$. evansi in different geographical areas within the same country (Aregawi et al. 2015; Bogale et al., 2012; Delafosse \& Doutoum 2004; Dia et al. 1997; Mirshekar et al. 2017; Olani et al. 2016; Salah, Robertson \& Mohamed 2019; Tehseen et al. 2015). In most cases, these within country differences can be explained by the observed variation in ecological factors (e.g., pastoral camel densities, hottest, most humid and wettest districts in the region) that affect vector densities and therefore infection prevalence (Hagos et al. 2009). Interestingly, geographical variation was not considered in some recent animal-level studies of Trypanosoma seroprevalence (Ghaemi, Zavarib \& Jannati Pirouz 2019; Hassan-Kadle et al. 2019; Salah et al. 2019). The geographical distribution of the parasite and vectors, and thus the occurrence of trypanosomosis, is largely dependent on the nature of the agro-ecological environment. Trypanosomosis, therefore, is regarded as endemic in certain regions (Holt et al. 2016). The climate is thought to permit and promote high densities of vectors such as the Tabanides fly (James et al. 1985).

Seropositivity for T. evansi infection was not associated with breed in our study. This result is in contrast with the studies that identified breed as a risk factor for T. evansi infection (e.g., in Chad; Delafosse \& Doutoum 2004). It seems likely, however, that the confounding effects of breed and hair colour make interpretation of any potential breed effect difficult. Animals with dark hair ('Zerga') were three times more likely to be infected than camels with other colours of hair coat (Boushaki et al. 2019). Similarly, white-coloured camels in Saudi Arabia were more likely to be infected with $T$. evansi than animals with 
a dark coat (El-Wathig et al., 2016). Further complicating the interpretation of potential breed effects is the notion that various colour coat phenotypes may belong to the same genotypes (Almathen, Mwaracharo \& Hanotte 2012; Cherifi et al. 2017). It should be noted that some other studies showed that camels were equally susceptible to Trypanosoma infection regardless of breed (Pathak \& Khanna 1995).

No difference in T. evansi seropositivity was observed between male and female camels in our study. There are conflicting reports in the literature, however, regarding the effect of sex. Some studies reported that Trypanosoma infection rate was higher for females than males (Dia et al. 1997; Shah et al. 2004; Sobhy et al. 2017). Contrarily, one study in Mali (Ndoutamia et al. 1999) found higher rates of infection amongst males - a finding supported by a Kenyan study where Trypanosoma infection rates were 2.6 times higher in males than females (Njiru et al. 2004). These conflicting results may be explained by interactions with other factors, disproportionate sampling of males versus females or differential application of husbandry practices to male versus female camels. In many countries, male camels are housed in a pen or tied when females go to the rangelands for grazing. This differential management approach may explain apparent sex differences rather than there being an actual biological predisposition to infection linked to camel sex.

Serologic testing is an important method for detecting parasitic infections. The direct card agglutination test (CATT test) is a validated test that is considered a rapid tool of choice for detection of T. evansi infection in camels (Dia et al. 1997; Ngaira et al. 2003), buffalos (Davison et al. 1999) and cattle (Reid \& Copeman 2003). The CATT test has been the test of choice for field investigations, despite the low sensitivity reported in some studies: 65.5\% (Ngaira et al. 2003) and $68.6 \%$ (Njiru et al. 2004). The T. evansi direct card agglutination test (CATT) uses latex agglutination of beads coated with recombinant antigens RoTat 1.2 VSG (Manual 2012). Moreover, other reports (Benfodil et al. 2020; Diall et al. 1994; Gutierrez et al. 2000; Pathak et al. 1997) have shown a moderate to strong agreement between CATT and other diagnostic methods such as trypanosome lysis (TL), WCL ELISA and RoTat 1.2 type A ELISA. Recent validation studies on serologic tests for T. evansi infection in camels and other ruminants showed the degree of concordance was highest between TL and T. evansi CATT $(k=0.784)$, thus confirming the interest of using T. evansi CATT for serodiagnosis of surra in the field (Benfodil et al. 2020).

Because of its mechanical means of transmission, T. evansi may be disseminated through a wide range of vectors. The multitude of potential vectors allowed Trypanosoma to become the most widespread pathogens in tropical and subtropical areas (Hoare 1972). Although T. evansi is not pathogenic to humans, human infestation by this parasite was first reported in India (Joshi et al. 2005). A follow-up study (Shegokar et al. 2006) reported a $22.7 \%$ T. evansi seroprevalence in humans in India. This finding is probably the consequence of frequent exposure of humans to T. evansi-infected livestock.
Camel farmers can experience considerable economic losses because of T. evansi infections because they result in outbreaks of abortions (and subsequent loss of replacement breeding stock or meat animals), decreased milk production, loss of body condition, decline of production efficiency and increased mortality. Additional financial losses occur because of premature culling of sick animals and biannual treatments administered to $T$. evansi seropositive animals. These devastating financial impacts point out the need to establish effective surveillance, control and prevention programmes.

Conditions in which contact with a vector is enhanced, such as sedentary camels sharing a common water source in an oasis or contact between animals and target potential reservoirs, are common in camel rearing (Elamin et al. 1998). In the particular case of camel husbandry in Africa, nomadism is characterised by migration during the dry season to areas with bioclimatic areas or conditions favouring survival of the vectors (e.g., woodlands, valleys, permanent water). Nomadism, therefore, is an important risk factor (Baumann \& Zessin, 1992; Delafosse \& Doutoum, 2004; Dia et al. 1997; Ngaira et al. 2003).

In the present study, T. evansi seroprevalence in individual camels in large camel herds reached $52 \%$, which corresponded to a risk of infection that was 2.1 times higher than camels from small herds. This higher risk is probably because of the fact that, in large farms, the infection pressure is stronger with more frequent contact between infected and non-infected animals. Our results agree with a study in Chad, which revealed that the largest herds were associated with a higher risk of trypanosomosis (Delafosse \& Doutoum 2004).

The source of water (e.g., rivers versus artificial wells) was a major risk factor for exposure to T. evansi in our study. Herds whose primary water source was a river had greater rates of infection than herds that drank from wells. Also, the presence of a dense canopy and permanent ponds create ideal breeding conditions for various species of tabanids, thus promoting spread of the disease (Doutoum et al. 2002). Where feasible, camel farmers should reduce access to naturally occurring water sources and instead provide well water.

\section{Conclusion}

Dromedary camels in eastern Algeria showed high rates of seropositivity for T. evansi at both the individual and herd levels. At the individual level, the three main risk factors for trypanosomosis were herd size, animal management system and accessibility to naturally occurring sources of water (rivers, lakes). Herd seroprevalence varied to a much lesser extent because of geographical location (district). These findings stress the importance of an integrated disease surveillance system for $T$. evansi. Preventive measures are needed to improve the health status of camel herds and to reduce the economic losses associated with outbreaks of camel trypanosomosis (which include abortions, cachexia, decreased productivity and mortality). 
Preventive measures may include surveillance of animal movements, particularly in rural areas. Studies employing more sensitive molecular diagnostic techniques, as well as epidemiological surveys to estimate seroprevalence at a national level, are needed to develop an efficient control strategy to avoid an endemic state of disease. In the context of global climate change, trypanosomiasis has been recognised as a re-emerging disease and a serious and economically important health issue with particular interest for Africa and Asia.

\section{Acknowledgements}

We gratefully acknowledge Dr Nedjima Abderrahmane, Morsli Ismail and Ninouh Med Kamel for assisting with the collection of blood samples, and we express sincere thanks to Mimouni Fatima Zohra, Absa Oumelkheir and Bensedik Imane for performing serology.

\section{Competing interests}

The authors have declared that no competing interests exist.

\section{Authors' contributions}

B.M.H., K.R. and B.F. conceived and designed the study and performed the laboratory investigations. B.M.H. and B.Y. contributed to field work, sample collection, epidemiological analysis and performed the laboratory investigations. B.M.H., B.A. and H.Y. analysed the data. B.M.H., C.Y., M.N. and K.T. contributed to the literature review, writing and editing of the manuscript.

\section{Funding information}

The General Directorate of Scientific Research and Technological Development (DGRSDT) and Scientific and Technical Research Center for Arid Areas (CRSTRA) provided funding the project, including scientific and technical support for laboratory analyses; we gratefully acknowledge this funding with tremendous thanks and appreciation.

\section{Data availability statement}

The data generated from this study are available from the corresponding author upon reasonable request.

\section{Disclaimer}

The views and opinions expressed in this article are those of the authors and do not necessarily reflect the official policy or position of any affiliated agency of the authors.

\section{References}

Abdel-Rady, A., 2008, 'Epidemiological studies (parasitological, serological and molecular techniques) of Trypanosoma evansi infection in camels (Camelus dromedarius) in Egypt', Veterinary World 1(11), 325-328.

Almathen, F., Mwaracharo, J. \& Hanotte, O., 2012, 'Genetic diversity and relationships of indigenous Saudi Arabia camel Camelus dromedarius populations', in E.H. Johnson et al. (eds.), Proceedings 3rd ISOCARD Conference, Mascate, 29th January-1st February, pp. 40-41.
Al-Rawashdeh, O., Sharif, L., Al-Qudah, K. \& Al-Ani, F., 1999, 'Trypanosoma evansi infection in camels in Jordan', Revue D Elevage Et De Medicine Veterinaire Des Pays Tropicaux 52, 233-238. https://doi.org/10.1155/2013/194176

Aregawi, W.G., Kassa, T., Tarekegn, K.D., Brehanu, W.T., Haile, S.T. \& Kiflewahid, F.Z., 2015, 'Parasitological and serological study of camel trypanosomosis (surra) and associated risk factors in Gabi Rasu Zone, Afar, Ethiopia', Journal of Veterinary Medicine and Animal Health 7(6), 234-240. https://doi.org/10.5897/ MVMAH2015.0374

Atarhouch, T., Rami, M., Bendahman, M.N. \& Dakkak, A., 2003, 'Camel trypanosomosis in Morocco 1: Results of a first epidemiological survey', Veterinary Parasitology 111(4), 277-286. https://doi.org/10.1016/s0304-4017(02)00382-5

Boushaki D., 2007, Prévalence de la trypanosomose cameline en Algérie, MSc thesis École Nationale Supérieure Vétérinaire d'Alger, Bab Ezzouar, p. 106 viewed 10 december 2019, from http://archive.ensv.dz:8080/jspui/handle/ $123456789 / 215$

Bajyana Songer, E. \& Hamers, R., 1988, 'A card agglutination test (CATT) for veterinary use based on an early VAT RoTat $1 / 2$ of Typanosoma evansi', Annales de la Société belge de médecine tropicale 68, 233-240, viewed 05 June 2019, from http://lib. itg.be/open/asbmt/1988/1988asbm0233.pdf.

Baumann, M.P. \& Zessin, K.H., 1992, 'Productivity and health of camels (Camelus dromedarius) in Somalia: Associations with trypanosomosis and brucellosis Tropical Animal and Health Production 24, 145-156. https://doi.org/10.1007/ BF02359606

Benaissa, M., Mayouf, R., Hamad, B., Saidi, M., Mehdaoui, A. \& Belhamra, M., 2012, 'Husbandry practices of camel herders in the region of El-Oued (southeast of Algeria)', in Proceeding of the 3rd Conference of the ISOCARD (Challenges Facing the Camelids in a Changing World and Climate), 29 January - 01 February 2012, Sultan Qabos University, Mascate, Sultanate of Oman, pp. 163-164.

Benfodil, K., Buscher, P., Abdelli, A., Van Reet, N., Mohamed-Herif, A., Ansel, S. et al., 2020. 'Comparison of serological and molecular tests for detection of Trypanosoma evansi in domestic animals from Ghardaia district, South Algeria', Veterinary Parasitology 280, 109089. https://doi.org/10.1016/j.vetpar. 2020.109089

Bennoune, O., Adili, N., Amri, K., Bennecib, L. \& Ayachi, A., 2013, 'Trypanosomiasis of camels (Camelus dromedarius) in Algeria: First report', Veterinary Research Forum 4(4), 273-275

Bogale, B., Kelemework, F. \& Chanie, M., 2012, 'Trypanosomosis in camel (Camelus dromedarius) in Delo-Mena District, Bale Zone, Oromia Region, Southwest Ethiopia', Acta Parasitologica Globalis 3(1), 12-15. https://doi.org/10.5829/idosi. apg.2012.3.1.7115

Boushaki, D., Adel, A., Dia, M.L., Buscher, P., Madani, H., Brihoum, B.A. et al., 2019, 'Epidemiological investigations on Trypanosoma evansi infection in dromedary camels in the South of Algeria', Heliyon 5(7), e02086. https://doi.org/10.1016/j. heliyon.2019.e02086

Chaudhary, Z. \& Iqbal, J., 2000, 'Incidence, biochemical and haematological alterations induced by natural trypanosomosis in racing dromedary camels', Acta Tropica 77(2), 209-213. https://doi.org/10.1016/s0001-706x(00)00142-x

Cherifi, Y.A., Gaouar, S.B.S., Guastamacchia, R., El-Bahrawy, K.A., Abushady, A.M.A., Sharaf, A.A. et al., 2017, 'Weak genetic structure in northern African dromedary camels reflects their unique evolutionary history,' PLoS One 12(1), e0168672. camels reflects their unique evolutionary histor,
https://doi.org/10.1371/journal.pone.0168672

Davison, H., Thrusfield, M., Muharsini, S., Husein, A., Partoutomo, S., Rae, P. et al., 1999 , 'Evaluation of antigen detection and antibody detection tests for Trypanosoma evansi infections of buffaloes in Indonesia', Epidemiology \& Trypanosoma evansi infections of buffaloes in Indonesia', Epidemiology
Infection 123(1), 149-155. https://doi.org/10.1017\%2Fs0950268899002575

Delafosse, A. \& Doutoum, A.A., 2004, 'Prevalence of Trypanosoma evansi infection and associated risk factors in camels in eastern Chad', Veterinary Parasitology 119(2-3), 155-164. https://doi.org/10.1016/j.vetpar.2003.11.010

Desquesnes, M., Biteau-Coroller, F., Bouyer, J., Dia, M.L. \& Foil, L., 2009, 'Development of a mathematical model for mechanical transmission of trypanosomes and other pathogens of cattle transmitted by tabanids', International Journal for Parasitology pathogens of cattle transmitted by tabanids', International Journal
39(3), 333-346. https://doi.org/10.1016/j.ijpara.2008.07.004

Desquesnes, M., Holzmuller, P., Lai, D.-H., Dargantes, A., Lun, Z.-R. \& Jittaplapong, S., 2013, 'Trypanosoma evansi and surra: A review and perspectives on origin, history, distribution, taxonomy, morphology, hosts, and pathogenic effects', BioMed Research International 2013, 194176. https://doi.org/10.1155/2013/194176

Dia, M., 2006, 'Parasites of the camel in Burkina Faso', Tropical Animal Health and Production 38(1), 17-21. https://doi.org/10.1007/s11250-006-4303-x

Dia, M.L., Diop, C., Aminetou, M., Jacquiet, P. \& Thiam, A., 1997, 'Some factors affecting the prevalence of Trypanosoma evansi in camels in Mauritania', Veterinary Parasitology 72(2), 111-120. https://doi.org/10.1016/S03044017(97)00054-X

Diall, O., Bajyana Songa, E., Magnus, E., Kouyate, B., Diallo, B., Meirvenne, N. et al., 1994, 'Evaluation d'un test sérologique d'agglutination directe sur carte dans le diagnostic de la Trypanosomose camèline à Trypanosoma evansi', Revue Scientifique et Technique. OIE 13, 793-800. https://doi.org/10.20506/rst.13.3.793

Doutoum, A.A., Delafosse, A., Elsen, P. \& Delafosse, S.A., 2002, 'Vecteurs potentiels de Trypanosoma evansi chez le dromadaire au Tchad oriental', Révue d'Élevage et de Médecine vétérinaire des Pays tropicaux 55, 21-30. https://doi.org/10.19182/ remvt.9841

Elamin, E., El Bashir, M. \& Saeed, E., 1998, 'Prevalence and infection pattern of Trypanosoma evansi in camels in mid-eastern Sudan', Tropical Animal Health and Production 30, 107-114. https://doi.org/10.1023/A:1005047801206

El-Wathig, M. \& Faye, B., 2013, 'Surveillance of camel trypanosomosis in Al-Jouf región, Saudi Arabia', Camel-International Journal of Veterinary Sciences 1(1), 89-98. 
El-Wathig, M., Faye, B., Thevenon, S., Ravel, S. \& Bosssard, G., 2016, 'Epidemiological surveys of camel trypanosomosis in Al-jouf, Saudi Arabia based on PCR and ELISA' surveys of camel trypanosomosis in Al-jouf, Saudi Arabia based on PCR and ELISA',
Emirates Journal of Food and Agriculture 28(3), 212-216. https://doi.org/10.9755/ ejfa.2015-09-759

Eshetu, Z., Desta, B. \& Amare, L., 2013, 'Prevalence of Trypanosoma evansi infection in the one-humped camel (Camelus dromedarius) in Jijiga administrative zone of the Ethiopian Somali region', Global Veterinaria 10(2), 233-238. https://doi. the Ethiopian Somali region', Global
org/10.5829/idosi.gv.2013.10.2.65167

Fikru, R., Andualem, Y., Getachew, T., Menten, J., Hasker, E., Merga, B. et al., 2015, 'Trypanosome infection in dromedary camels in Eastern Ethiopia: Prevalence, relative performance of diagnostic tools and host related risk factors', Veterinary Parasitology 211(3-4), 175-181. https://doi.org/10.1016/j.vetpar.2015.04.008

Ghaemi, M., Zavarib, A. \& Jannati Pirouz, H., 2019, 'Evaluation of Trypanosama evansi prevalence and risk factors in the one-humped camels (Camelus dromedarius) of the north-east of Iran by a real-time PCR test', Preventive Veterinary Medicine 168, 60-65. https://doi.org/10.1016/j.prevetmed.2019.04.013

Gutierrez, C., Corbera, J.A., Juste, M.C., Doreste, F. \& Morales, I., 2005, 'An outbreak of abortions and high neonatal mortality associated with Trypanosoma evansi infection in dromedary camels in the Canary Islands', Veterinary Parasitology 130(1-2), 163-168. https://doi.org/10.1016/j.vetpar.2005.02.009

Gutierrez, C., Juste, M.C., Corbera, J.A., Magnus, E., Verloo, D. \& Montoya, J.A., 2000 'Camel trypanosomosis in the Canary Islands: Assessment of seroprevalence and infection rates using the card agglutination test (CATT/T. evansi) and parasite detection tests', Veterinary Parasitology 90(1-2), 155-159. https://doi. org/10.1016/s0304-4017(00)00225-9

Hagos, A., Yilkal, A., Esayass, T., Alemu, T., Fikru, R., Ab Feseha, G. et al., 2009, 'Parasitological and serological survey on trypanosomis (surra) in camels in dry and wet areas of Bale Zone, Oromyia Region, Ethiopia', Revue de médecine vétérinaire 160(12), 569-573.

Hasan, M.U., Muhammad, G., Gutierrez, C., Iqbal, Z., Shakoor, A. \& Jabbar, A., 2006 'Prevalence of Trypanosoma evansi infection in equines and camels in the Punjab region, Pakistan', Annals of the New York Academy of Sciences 1081(1), 322-324. https://doi.org/10.1196/annals.1373.043

Hassan-Kadle, A.A., Ibrahim, A.M., Nyingilili, H.S., Yusuf, A.A., Vieira, T. \& Vieira, R.F.C., 2019, 'Parasitological, serological and molecular survey of camel trypanosomiasis in Somalia', Parasites Vectors 12, 598. https://doi.org/10.1186/ s13071-019-3853-5

Hoare, C., 1972, The trypanosomes of mammals: A zoological monograph, Blackwell Scientific Publications, Oxford

Holt, H., Selby, R., Mumba, C., Napier, G. \& Guitian, J., 2016, 'Assessment of animal African trypanosomiasis (AAT) vulnerability in cattle-owning communities of subSaharan Africa', Parasites \& Vectors 9, 53. https://doi.org/10.1186/s13071-016 1336-5

James, M.A., Coronado, A., Lopez, W., Melendez, R. \& Ristic, M., 1985, 'Seroepidemiology of bovine anaplasmosis and babesiosis in Venezuela', Tropical Animal Health and Production 17, 9-18.

Joshi, P.P., Shegokar, V.R., Powar, R.M., Herder, S., Katti, R., Salkar, H.R. et al., 2005 'Human trypanosomiasis caused by Trypanosoma evansi in India: The first case report', The American Journal of Tropical Medicine and Hygiene 73(3), 491-495. https://doi.org/10.4269/ajtmh.2005.73.491

Lemecha, H., Lidetu, D. \& Hussein, I., 2008, 'Prevalence and distribution of came trypanosomosis in the semi-arid and arid Awash Valley of Ethiopia. Ethiopian Journal of Animal Production 8(1), 1-9.

Luckins, A., 1998, 'Epidemiology of surra: Unanswered questions', The Journal of Protozoology Research 8(3), 106-119.

Mandal, M., Laha, R., Pandit, S. \& Sasmal, N.K., 2017, 'Oral route of transmission: Trypanosoma evansi in a mice model experiment', Journal of Parasitic Diseases 41(3), 880-882. https://doi.org/10.1007/s12639-017-0910-x

Manual, OIE Terrestrial, 2012, Trypanosoma evansi infection (surra), viewed 05 March 2019, from https://www.oie.int/fileadmin/Home/eng/Health_standards/tahm/ 3.01.21_TRYPANO_SURRA.pdf.

Mirshekar, F., Yakhchali, M. \& Shariati-Sharifi, F., 2017, 'Trypanosoma evansi infection and major risk factors for Iranian one-humped camels (Camelus dromedarius)', Journal of Parasitic Diseases 41(3), 854-858. https://doi.org/10.1007/s12639017-0905-7

Mohamed, M., Mohamoud, A., Adow, H. \& Bitrus, A., 2020, 'Seroprevalence of Trypanosoma evansi in dromedary camels from selected dairy farms in Benadir, Somalia', Advances in Animal and Veterinary Sciences 8(3), 333-338. https://doi. org/0.17582/journal.aavs/2020/8.3.333.338
More, S., Bøtner, A., Butterworth, A., Calistri, P., Depner, K., Edwards, S. et al., 2017, 'Assessment of listing and categorisation of animal diseases within the framework of the Animal Health Law (Regulation (EU) No 2016/429): Paratuberculosis', European Food Safety Authority Journal 15(11), e05071. https://doi.org/10.2903/j. efsa.2017.5071

Ndoutamia, G., Brahim, B., Brahim, A., Djimgang, G., Saboun, M. \& Doutoum, A. 1999, 'La trypanosomose a trypanosoma evansi chez les camelides au tchad: Facteurs epidemiologiques et influence sur les parametres hematologiques et proteo-energetiques', Revue de Médecine Vétérinaire 150, 899-904.

Ngaira, J., Bett, B., Karanja, S. \& Njagi, E., 2003, 'Evaluation of antigen and antibody rapid detection tests for Trypanosoma evansi infection in camels in Kenya', Veterinary Parasitology 114(2), 131-141. https://doi.org/10.1016/s0304-4017(03)00112-2

Njiru, Z., Brett, B., Ole-Mapeny, I., Githiori, J. \& Ndung'u, J., 2002, 'Trypanosomosis and helminthosis in camels: Comparison of ranch and traditional camel management systems in Kenya', Journal of Camel Practice and Research 9(1), 67-71.

Njiru, Z., Constantine, C., Ndung'u, J., Robertson, I., Okaye, S., Thompson, R. et al., 2004, Detection of Trypanosoma evansi in camels using PCR and CATT/T. evans tests in Kenya', Veterinary Parasitology 124(3-4), 187-199. https://doi. org/10.1016/j.vetpar.2004.06.029

Olani, A., Habtamu, Y., Wegayehu, T. \& Anberber, M., 2016, 'Prevalence of came trypanosomosis (surra) and associated risk factors in Borena zone, southern Ethiopia', Parasitology Research 115(3), 1141-1147. https://doi.org/10.1007/ s00436-015-4845-9

Pacholek, X., Gamatie, D., Vias Franck, S. \& Tibayrenc, R., 2000. 'Prévalence de la trypanosomose Trypanosoma evansi chez les chamelons de l'ouest nigérien', Revue d'élevage et de Médecine Vétérinaire des Pays Tropicaux 53(2), 177-182. https://doi.org/10.19182/remvt.9748

Pathak, K. \& Khanna, N., 1995, 'Trypanosomosis in camel (Camelus Dromedarius) with particular reference to Indian sub-continent: A review' International Journal of Animal Sciences 10, 157-157.

Pathak, K.M., Singh, Y., Meirvenne, N.V. \& Kapoor, M., 1997, 'Evaluation of various diagnostic techniques for Trypanosoma evansi infections in naturally infected
camels', Veterinary Parasitology 69(1-2), 49-54. https://doi.org/10.1016/S0304camels', Veterinary

Reid, S. \& Copeman, D., 2003, 'The development and validation of an antibody-ELISA to detect Trypanosoma evansi infection in cattle in Australia and Papua New Guinea', Preventive Veterinary Medicine 61(3), 195-208. https://doi. Guinea', Preventive Veterinary Medic
org/10.1016/j.prevetmed.2003.07.004

Salah, A.A., Robertson, I. \& Mohamed, A., 2015, 'Estimating the economic impact of Trypanosoma evansi infection on production of camel herds in Somaliland' Tropical Animal Health and Production 47(4), 707-714. https://doi.org/10.1007/ s11250-015-0780-0

Salah, A.A., Robertson, I.D. \& Mohamed, A.S., 2019, 'Prevalence and distribution of Trypanosoma evansi in camels in Somaliland', Tropical Animal Health and Production 51(8), 2371-2377. https://doi.org/10.1007/s11250-019-01947-6

Sergent, E. \& Sergent, E., 1905, EL-DEBAB Trypanosomiase des dromadaires de IAfrique du Nord, Annales de I'Institut Pasteur d'Alger, pp. 17-48.

Shah, S., Phulan, M., Memon, M., Rind, R. \& Bhatti, W., 2004, 'Trypanosomes infection in camels', Pakistan Vetrinary Journal 24(4), 209-210.

Shegokar, V.R., Powar, R.M., Joshi, P.P., Bhargava, A., Dani, V.S., Katti, R. et al., 2006 'Human trypanosomiasis caused by Trypanosoma evansi in a village in India: Preliminary serologic survey of the local population', The American Journal of Tropical Medicine and Hygiene 75(5), 869-870. https://doi.org/10.4269/ ajtmh.2006.75.869

Sobhy, H.M., Barghash, S.M., Behour, T.S. \& Razin, E.A., 2017, 'Seasonal fluctuation of trypanosomiasis in camels in North-West Egypt and effect of age, sex, location, health status and vector abundance on the prevalence', Beni-Suef University Journal of Basic and Applied Sciences 6(1), 64-68. https://doi.org/10.1016/j.bjbas.2017.01.003

Stoco, P.H., Miletti, L.C., Picozzi, K., Steindel, M. \& Grisard, E.C., 2017, 'Other major trypanosomiasis', in C.B. Marcondes (ed.), Arthropod borne diseases, pp. 299-324, Springer, Berlin.

Tehseen, S., Jahan, N., Qamar, M.F., Desquesnes, M., Shahzad, M.I., Deborggraeve, S. et al., 2015, 'Parasitological, serological and molecular survey of Trypanosoma evansi infection in dromedary camels from Cholistan Desert, Pakistan', Parasites \& Vectors 8(1), 415. https://doi.org/10.1186/s13071-015-1002-3

Thrusfield, M., 2018, Veterinary epidemiology, John Wiley \& Sons, Hoboken, NJ.

Zarif-Fard, M. \& Hashemi-Fesharki, R., 2000, 'Study on tissue and blood protozoa of camels in southern Iran',. Journal of Camel Practice and Research 7(2), 193-194. https://doi.org/10.22092/ARI.2000.109209 